\title{
Crosslinked Polycarbosilanes. Synthesis and Properties
}

\author{
Manabu TSUMURA and Takahisa IWAHARA \\ Kobe Research Laboratories, Performance Materials R\&D Center, Kaneka Corporation, \\ 1-2-80, Yoshida-cho, Hyogo-ku, Kobe 652-0872, Japan
}

(Received November 17, 1999)

\begin{abstract}
New crosslinked polycarbosilanes (PCSs) having biphenyl, biphenyl ether and naphthalene linkages, were synthesized by hydrosilylation reaction between multi-functional vinylsilanes and hydrosilanes. The PCSs were transparent rigid material without cracks or bubbles. The mechanical properties and glass transition temperatures $\left(T_{\mathrm{g}} \mathrm{s}\right)$ of the PCSs were evaluated by flexural tests and differential scanning calorimeter (DSC) or dynamic mechanical analysis (DMA). Crosslinked PCSs VIII-X with high network chain density and rigid-rod spacers had $T_{\mathrm{g}} \mathrm{s}$ at around $250^{\circ} \mathrm{C}$ and high flexural strength in the range of $75-96 \mathrm{MPa}$. 5\% weight loss temperatures of PCSs under nitrogen ranged from $490^{\circ} \mathrm{C}$ to $544^{\circ} \mathrm{C}$.

KEYWORDS Polycarbosilane / Crosslinked Polymer / Hydrosilylation Reaction / Mechanical Behavior / Thermal Property / Network Chain Density/Rigid-Rod Spacer /
\end{abstract}

Much attention has been focused on the structures and properties of polycarbosilanes (PCSs), containing $\mathrm{Si}-\mathrm{C}$ bonds in polymer backbones. ${ }^{1-3}$

Recently, the authors reported the synthesis and properties of linear PCSs produced by hydrosilylation polymerization. ${ }^{4,5}$ The synthesis and applications of crosslinked PCSs have been reported by Friedmann by hydrosilylation reaction and various carbon-based compounds as monomers which have vinyl groups. ${ }^{6}$

We demonstrated that the high network chain density and rigid-rod unit, $\left[\mathrm{Si}(\mathrm{Me})_{2}-p-\mathrm{C}_{6} \mathrm{H}_{4}-\mathrm{Si}(\mathrm{Me})_{2}\right]$, was necessary to give high mechanical strength to crosslinked PCSs (Table I, PCS II). ${ }^{7}$ The present investigation obtained crosslinked PCS having a high $T_{\mathrm{g}}$ and good mechanical properties by introducing of rigid-rod spacer units, biphenyl and naphthalene linkages to PCS monomers. At first, spacer structures were optimized to increase $T_{\mathrm{g}} \mathrm{s}$ and flexural properties, and network chain density was optimized. This article reports the synthesis of novel vinylsilanes and hydrosilanes. The mechanical properties and thermal stability are described.

\section{EXPERIMENTAL}

\section{Molecular Characterization}

${ }^{1} \mathrm{H}$ NMR spectra were recorded in $\mathrm{CDCl}_{3}$ on a Bruker AMX-400. The high-resolution solid-state ${ }^{29} \mathrm{Si}$ NMR spectra were obtained by the combined use of dipolardecoupling (DD) and magic-angle spinning (MAS) ${ }^{8.9}$ Spinning frequency was $5.0 \mathrm{kHz}$. Mass spectra were obtained on a Shimadzu GCMS QP-2000 A.

\section{Thermal Characterization}

Glass-transition temperatures were determined using a Shimadzu differential scanning calorimeter (DSC-50). Samples $(5 \mathrm{mg}$ ) were used, and data from the second heating run were reported for a heating rate of $20^{\circ} \mathrm{C}$ $\min ^{-1}$ and a nitrogen atmosphere. Thermogravimetric analysis (TGA) was carried out on a Shimadzu TGA-50 thermal analyzer at heating rate of $20^{\circ} \mathrm{C} \mathrm{min}{ }^{-1}$ under a nitrogen atmosphere. Temperatures at $5 \%$ weight loss, $T_{\mathrm{d} 5}$, were noted.

Table I. Flexural properties and $T_{\mathrm{g}} \mathrm{s}$ of crosslinked PCSs at $23^{\circ} \mathrm{C}$

PCS I

\footnotetext{
${ }^{\mathrm{a}}$ By DSC.
} 


\section{Mechanical Characterization}

A three-point bending test was performed with a Shimadzu AUTO-GRAPH at maximum load cell of $100 \mathrm{~kg}$, and a cross-head speed of $0.9 \mathrm{~mm} \mathrm{~min}^{-1}$ (JIS K 7203). The test at 200 or $250^{\circ} \mathrm{C}$ was performed 10 min later at setting specimen. Specimens, bars $(4.0 \times 0.6 \times \sim 0.14$ $\mathrm{cm}$ ), were cut from the cured sample by a cutter with a diamond-blade. DMA (dynamic mechanical analysis) was performed with a ITK DVA-200 in tensile mode at oscillation frequency of $10 \mathrm{~Hz}$. The heating rate was $4^{\circ} \mathrm{C}$ $\min ^{-1}$.

\section{Materials}

Dimethylvinylchlorosilane, dimethylchlorosilane and 1,3,5,7-tetramethylcyclotetrasiloxane (2) were purchased from Shin-Etsu Chemical Co., Ltd. Trivinylchlorosilane was purchased from Gelest Inc. 4,4'-dibromobiphenyl, 4-bromobiphenylether, dimethyl maleate and $\mathrm{Mg}$ were purchased from TOKYO KASEI Co., Ltd. 1,5dibromonaphthalene and 2,6-dibromonaphalene were from HODOGAYA CONTRACT LABORATORY Co., Ltd. Tetrahydrofuran (THF, Nacalai Tesque Co., Ltd.) was dried over $\mathrm{Na}$ /benzophenone and distilled before use during synthesis of monomer. The platinum catalyst [Pt $\left.\left\{\left(\mathrm{CH}_{2}=\mathrm{CHSiMe}_{2}\right)_{2} \mathrm{O}\right\}_{2}\right\}(3.0 \mathrm{wt} \% \mathrm{Pt})$ was purchased from Degussa Co., Ltd.

\section{Synthesis of Monomer}

The monomers (5)-(12) were synthesized following the same experimental procedure ${ }^{5}$ shown in Scheme 1.

\section{4,4'-Bis(dimethylvinylsilyl)biphenyl (5)}

In a $200-\mathrm{mL}$ three-necked round-bottomed flask equipped with a Teflon-covered magnetic stirring bar, a

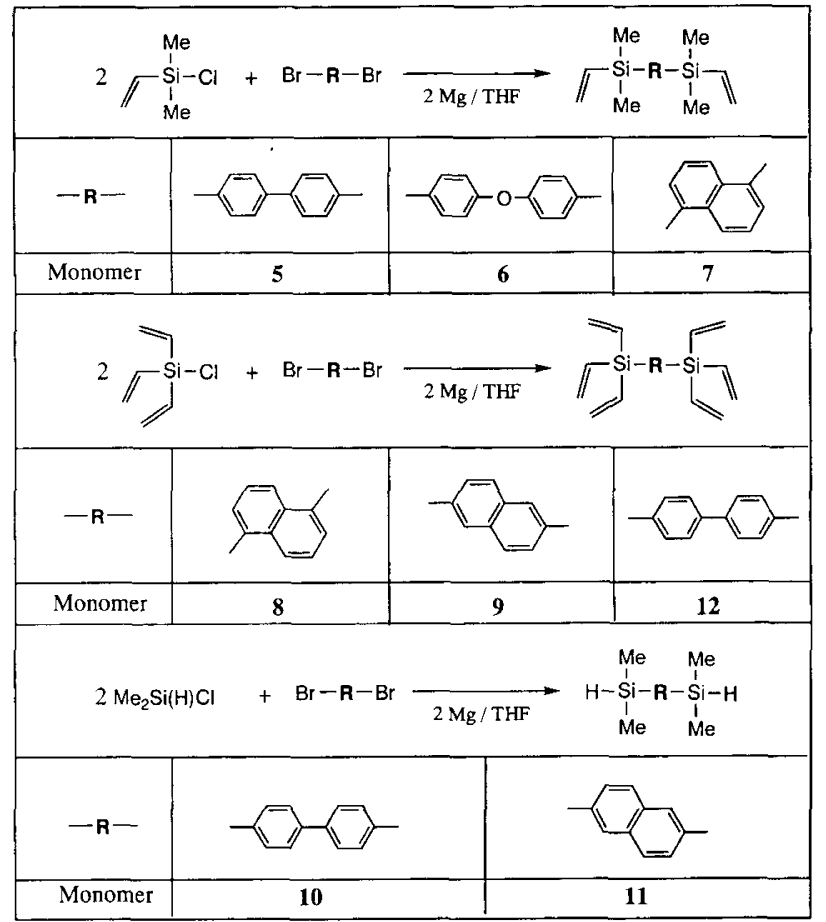

Scheme 1. Synthesis of PCS monomers. dropping funnel and a reflux condenser were placed magnesium turnings $(1.0 \mathrm{~g}, 41 \mathrm{mmol})$, dimethylvinylchlorolsilane $(5.0 \mathrm{~g}, 41 \mathrm{mmol})$, and THF (20 mL). A solution of 4,4'-dibromobiphenyl $(6.4 \mathrm{~g}, 21 \mathrm{mmol})$ in $50 \mathrm{~mL}$ of THF was slowly added for $1 \mathrm{~h}$ at room temperature. The mixture was stirred for $4 \mathrm{~h}$ under reflux and $12 \mathrm{~h}$ at room temperature. Hexane and water were added to the reaction mixture. The organic layer was separated and washed with brine. The organic layer was dried over anhydrous sodium sulfate and filtered, and the solvents were removed by evaporation under reduced pressure. Distillation of the residue under reduced pressure (135 $\left.-140^{\circ} \mathrm{C} / 0.3 \mathrm{mmHg}\right)$ gave $2.6 \mathrm{~g}(39 \%)$ of $(5)$.

GC/MS (m/e, \%) $322\left(\mathrm{M}^{+}, 34\right), 307\left(\mathrm{M}^{+}-15,94\right), 59$ (100). ${ }^{1} \mathrm{H}$ NMR $\left(\mathrm{CDCl}_{3}\right) \delta 0.37\left(\mathrm{~s}, \mathrm{SiCH}_{3}, 12 \mathrm{H}\right), 5.78(\mathrm{dd}$, $\mathrm{CH}_{2}=\mathrm{CH}^{-}$, trans, $J=20,4 \mathrm{~Hz}, 2 \mathrm{H}$ ), 6.07 (dd, $\mathrm{CH}_{2}=$ $\mathrm{CH}^{-}$, cis $\left., J=15,4 \mathrm{~Hz}, 2 \mathrm{H}\right), 6.31$ (dd, $\mathrm{CH}_{2}=\mathrm{CH}-, J=20$, $15 \mathrm{~Hz}, 2 \mathrm{H}), 7.58$ (d, aromatic, $8 \mathrm{H})$.

\section{Bis(4-dimethylvinylsilylphenyl)ether (6)}

Monomer (6) was synthesized in a similar manner for (5). Magnesium turnings $(2.5 \mathrm{~g}, 105 \mathrm{mmol})$, dimethylvinylchlorolsilane $(12.4 \mathrm{~g}, 103 \mathrm{mmol})$, and 4-bromobiphenylether $(16.9 \mathrm{~g}, 52 \mathrm{mmol})$ were used. Distillation of the residue under reduced pressure $\left(150-160^{\circ} \mathrm{C} / 2.7 \mathrm{mmHg}\right.$ ) gave a colorless oil $7.4 \mathrm{~g} \mathrm{(42 \% )}$ of $(6)$.

(10).

GC/MS (m/e, \%) $338\left(\mathrm{M}^{+}, 23\right), 323\left(\mathrm{M}^{+}-15,100\right), 85$

\section{1,5-Bis(dimethylvinylsilyl)naphthalene (7)}

Monomer (7) was synthesized in a similar manner for (5). Magnesium turnings (2.5 g, $105 \mathrm{mmol})$, dimethylvinylchlorolsilane $(12.4 \mathrm{~g}, 103 \mathrm{mmol})$, and 1,5-dibromonaphthalene $(14.7 \mathrm{~g}, 52 \mathrm{mmol})$ were used. Distillation of the residue under reduced pressure $\left(144-160^{\circ} \mathrm{C} / 3.7\right.$ $\mathrm{mmHg})$ gave $5.8 \mathrm{~g} \mathrm{(38 \% )}$ of (7).

GC/MS (m/e, \%) $338\left(\mathrm{M}^{+}, 23\right), 323\left(\mathrm{M}^{+}-15,100\right), 85$ (10).

\section{1,5-Bis(trivinylsilyl)naphthalene (8)}

Monomer (8) was synthesized in a similar manner for (5). Magnesium turnings ( $3.6 \mathrm{~g}, 147 \mathrm{mmol}$ ), trivinylchlorolsilane $(21.3 \mathrm{~g}, 147 \mathrm{mmol})$, and 1,5-dibromonaphthalene $(20.0 \mathrm{~g}, 70 \mathrm{mmol})$ were used. Distillation of the residue under reduced pressure $\left(144-147^{\circ} \mathrm{C} / 0.4 \mathrm{mmHg}\right.$ ) gave $11.0 \mathrm{~g}(46 \%)$ of $(8) ; \mathrm{mp}, 54^{\circ} \mathrm{C}$.

GC/MS (m/e, \%) $344\left(\mathrm{M}^{+}, 15\right), 317\left(\mathrm{M}^{+}-27,11\right), 235$ $\left(\mathrm{M}^{+}-109,22\right), 83(100) .{ }^{1} \mathrm{H}$ NMR $\left(\mathrm{CDCl}_{3}\right) \delta 5.86(\mathrm{dd}$, $\mathrm{CH}_{2}=\mathrm{CH}^{-}$, trans, $\left.J=20,4 \mathrm{~Hz}, 6 \mathrm{H}\right), 6.22\left(\mathrm{dd}, \mathrm{CH}_{2}=\right.$ $\mathrm{CH}^{-}$, cis $\left., J=15,4 \mathrm{~Hz}, 6 \mathrm{H}\right), 6.47\left(\mathrm{dd}, \mathrm{CH}_{2}=\mathrm{CH}^{-}, J=20\right.$, $15 \mathrm{~Hz}, 6 \mathrm{H}), 7.43$ (dd, aromatic, $J=7,8 \mathrm{~Hz}, 2 \mathrm{H}), 7.77$ (d, aromatic, $J=7 \mathrm{~Hz}, 2 \mathrm{H}), 8.19(\mathrm{~d}$, aromatic, $J=8 \mathrm{~Hz}, 2 \mathrm{H})$.

\section{2,6-Bis(trivinylsilyl)naphthalene (9)}

Monomer (9) was synthesized in a similar manner for (5). Magnesium turnings ( $3.6 \mathrm{~g}, 147 \mathrm{mmol}$ ), trivinylchlorolsilane $(21.3 \mathrm{~g}, 147 \mathrm{mmol})$, and 2,6-dibromonaphthalene $(10.0 \mathrm{~g}, 35 \mathrm{mmol})$ were used. Distillation of the residue under reduced pressure $\left(140^{\circ} \mathrm{C} / 0.4 \mathrm{mmHg}\right)$ gave 
Table II. Preparation of crosslinked PCSs ${ }^{2}$

\begin{tabular}{|c|c|c|c|c|c|}
\hline & \multicolumn{2}{|c|}{ PCS monomers } & \multirow{2}{*}{$\begin{array}{l}\text { Pt cat. } \\
\left(\times 10^{-5}\right)\end{array}$} & \multirow{2}{*}{$\mathrm{DM}^{\mathrm{c}}$} & \multirow{2}{*}{$\mathrm{THF} / \mathrm{mL}$} \\
\hline & Si-vinyl, $\mathrm{g} / \mathrm{mmol}$ & $\mathrm{Si}-\mathrm{H}, \mathrm{g} / \mathrm{mmol}$ & & & \\
\hline PCS III & $5,3.64(11.3)$ & $\mathbf{2}, 1.36(5.7)$ & 10 & 100 & 5 \\
\hline PCS IV & $6,3.69(10.9)$ & $2,1.31(5.5)$ & 1 & 100 & 5 \\
\hline PCS V & $7,3.56(12.0)$ & $2,1.44(6.0)$ & 1 & 100 & 5 \\
\hline PCS VI & $8,1.54(4.5)$ & $4,2.60(13.4)$ & 1 & 100 & 3 \\
\hline PCS VII & $\mathbf{9}, 1.54(4.5)$ & $4,2.60(13.4)$ & 1 & 100 & 3 \\
\hline PCS VIII & $\mathbf{9}, 1.04(3.0)$ & $10,2.39(8.8)$ & 1 & 100 & 3 \\
\hline PCS IX & $\mathbf{9}, 1.11(3.2)$ & $11,2.33(9.5)$ & 1 & 100 & 3 \\
\hline $\operatorname{PCS} \mathbf{x}$ & $12,1.37(3.7)$ & $10,2.92(10.8)$ & 1 & 100 & 4 \\
\hline
\end{tabular}

${ }^{\mathrm{a}}$ Curing conditions : PCS III $-\mathrm{V}: 50^{\circ} \mathrm{C} / 17 \mathrm{~h} \rightarrow 80^{\circ} \mathrm{C} / 5 \mathrm{~h} \rightarrow 100^{\circ} \mathrm{C} / 21 \mathrm{~h} \rightarrow 150^{\circ} \mathrm{C} / 24 \mathrm{~h}$ (in air), PCS VI, VII : $50^{\circ} \mathrm{C} / 20 \mathrm{~h} \rightarrow 80^{\circ} \mathrm{C} / 8 \mathrm{~h} \rightarrow$ $100^{\circ} \mathrm{C} / 16 \mathrm{~h} \rightarrow 150^{\circ} \mathrm{C} / 24 \mathrm{~h}$ (in air) $\rightarrow 100^{\circ} \mathrm{C} / 1 \mathrm{~h} \rightarrow 250^{\circ} \mathrm{C} / 1 \mathrm{~h}$ (in N $)_{2}$, PCS VIII, $\mathbf{I X}: 50^{\circ} \mathrm{C} / 19 \mathrm{~h} \rightarrow 80^{\circ} \mathrm{C} / 11 \mathrm{~h} \rightarrow 100^{\circ} \mathrm{C} / 13 \mathrm{~h} \rightarrow 150^{\circ} \mathrm{C} / 24 \mathrm{~h}$ (in air) $\rightarrow 100^{\circ} \mathrm{C} / 1 \mathrm{~h} \rightarrow 250^{\circ} \mathrm{C} / 1 \mathrm{~h}$ (in $\mathrm{N}_{2}$ ), PCS X : $50^{\circ} \mathrm{C} / 22 \mathrm{~h} \rightarrow 80^{\circ} \mathrm{C} / 10 \mathrm{~h} \rightarrow 100^{\circ} \mathrm{C} / 14 \mathrm{~h} \rightarrow 150^{\circ} \mathrm{C} / 24 \mathrm{~h}$ (in air) $\rightarrow 100^{\circ} \mathrm{C} / 1 \mathrm{~h} \rightarrow 280^{\circ} \mathrm{C} /$ $1 \mathrm{~h}$ (in $\left.\mathrm{N}_{2}\right)$. ${ }^{b} \mathrm{Pt}\left[\left(\mathrm{CH}_{2}=\mathrm{CHMe}_{2} \mathrm{Si}_{2}\right)_{2}\right]_{2}$, the mole equivalent rel. to the vinyl substituents of the Si-vinyl monomers. ${ }^{\text {c }}$ Relative amount of dimethylmaleate (DM) to platinum catalyst.

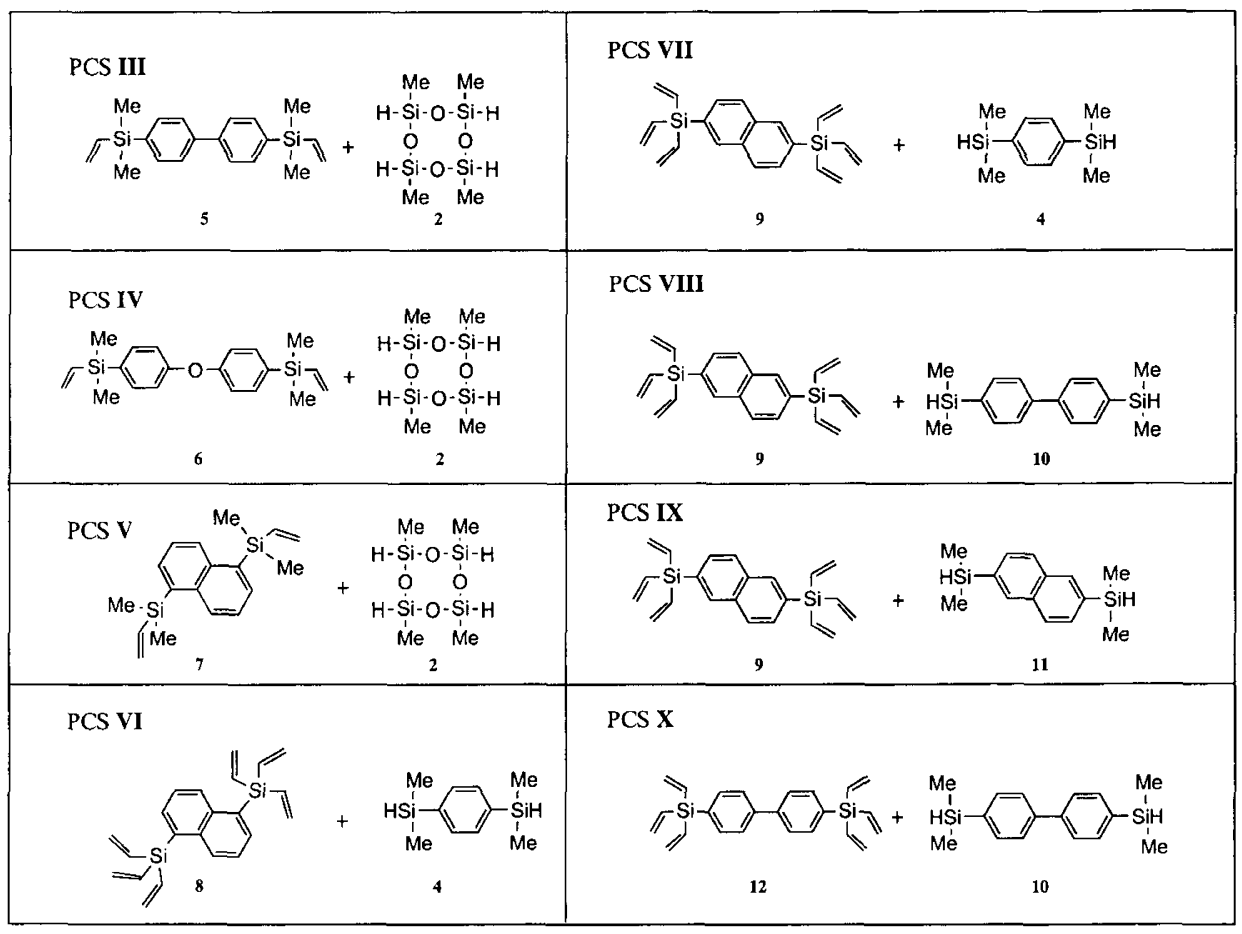

Scheme 2. Preparation of crosslinked PCSs III-X.

\section{$3.4 \mathrm{~g}(28 \%)$ of $(9) ; \mathrm{mp}, 28^{\circ} \mathrm{C}$.}

GC/MS (m/e, \%) $344\left(\mathrm{M}^{+}, 42\right), 317\left(\mathrm{M}^{+}-27,11\right), 235$ $\left(\mathrm{M}^{+}-109,54\right), 83(100) .{ }^{1} \mathrm{H}$ NMR $\left(\mathrm{CDCl}_{3}\right) \delta 5.88(\mathrm{dd}$, $\mathrm{CH}_{2}=\mathrm{CH}^{-}$, trans, $\left.\mathrm{J}=20,4 \mathrm{~Hz}, 6 \mathrm{H}\right), 6.26\left(\mathrm{dd}, \mathrm{CH}_{2}=\right.$ $\mathrm{CH}^{-}$, cis $\left., J=15,4 \mathrm{~Hz}, 6 \mathrm{H}\right), 6.42\left(\mathrm{dd}, \mathrm{CH}_{2}=\mathrm{CH}-, J=20\right.$, $15 \mathrm{~Hz}, 6 \mathrm{H}), 7.63(\mathrm{~d}$, aromatic, $J=8 \mathrm{~Hz}, 2 \mathrm{H}), 7.85(\mathrm{~d}$, aromatic, $J=8 \mathrm{~Hz}, 2 \mathrm{H}$ ), 8.06 (s, aromatic, $2 \mathrm{H}$ ).

\section{4,4'-Bis(trivinylsilyl)biphenyl (12)}

Monomer (12) was synthesized in a similar manner for (5). Magnesium turnings ( $3.4 \mathrm{~g}, 141 \mathrm{mmol})$, trivinylchlorolsilane $(27.8 \mathrm{~g}, 192 \mathrm{mmol})$, and $4,4^{\prime}$-dibromobiphenyl $(20.0 \mathrm{~g}, 64 \mathrm{mmol})$ were used. Distillation of the residue under reduced pressure $\left(160^{\circ} \mathrm{C} / 1.1 \mathrm{mmHg}\right)$ gave a colorless oil $7.9 \mathrm{~g} \mathrm{(30 \% )}$ of (12).

GC/MS (m/e, \%) $370\left(\mathrm{M}^{+}, 60\right), 343\left(\mathrm{M}^{+}-27,49\right), 261$ (100). ${ }^{1} \mathrm{H} \mathrm{NMR}\left(\mathrm{CDCl}_{3}\right) \delta 5.88\left(\mathrm{dd}, \mathrm{CH}_{2}=\mathrm{CH}-\right.$, trans, $J$
$=19,4 \mathrm{~Hz}, 6 \mathrm{H}), 6.26\left(\mathrm{dd}, \mathrm{CH}_{2}=\mathrm{CH}^{-}\right.$, cis $, J=15,4 \mathrm{~Hz}$, $6 \mathrm{H}), 6.39\left(\mathrm{dd}, \mathrm{CH}_{2}=\mathrm{CH}-, J=19,15 \mathrm{~Hz}, 6 \mathrm{H}\right), 7.64-7.65$ (aromatic, $8 \mathrm{H}$ ).

\section{4,4'-Bis(dimethylsilyl)biphenyl (10)}

In a $500-\mathrm{mL}$ three-necked round-bottomed flask equipped with a Teflon-covered magnetic stirring bar, a dropping funnel and a reflux condenser were placed magnesium turnings ( $3.4 \mathrm{~g}, 141 \mathrm{mmol}$ ), dimethylchlorolsilane (18.2 g, $192 \mathrm{mmol})$, and THF $(50 \mathrm{~mL})$. A solution of 4,4'-dibromobiphenyl $(20.0 \mathrm{~g}, 64 \mathrm{mmol})$ in $140 \mathrm{~mL}$ of THF was slowly added for $3 \mathrm{~h}$ at room temperature. The mixture was stirred for $8 \mathrm{~h}$ under reflux. To this was added dry hexane, and the salt formed was filtered off. The solvents were evaporated under reduced pressure. Distillation of the residue under reduced pressure (140 $\left.-150^{\circ} \mathrm{C} / 2.0 \mathrm{mmHg}\right)$ gave a colorless oil $10.6 \mathrm{~g}(58 \%)$ of (10).

GC/MS (m/e, \%) $270\left(\mathrm{M}^{+}, 42\right), 269\left(\mathrm{M}^{+}-1,16\right), 255$ 
$\left(\mathrm{M}^{+}-15,61\right), 211$ (100). ${ }^{1} \mathrm{H}$ NMR $\left(\mathrm{CDCl}_{3}\right) \quad \delta 0.43(\mathrm{~d}$, $\mathrm{SiCH}_{3}, J=4 \mathrm{~Hz}, 12 \mathrm{H}$ ), 4.35 (sept., $\mathrm{Si}-H, J=4 \mathrm{~Hz}, 2 \mathrm{H}$ ), $7.63-7.70$ (aromatic, $8 \mathrm{H}$ ).

\section{2,6-Bis(dimethylsilyl)naphthalene (11)}

Monomer (11) was synthesized in a similar manner for (10). Magnesium turnings $(3.4 \mathrm{~g}, 141 \mathrm{mmol})$, dimethylchlorolsilane $(18.2 \mathrm{~g}, 192 \mathrm{mmol})$, and 2,6-dibromonaphthalene $(18.3 \mathrm{~g}, 64 \mathrm{mmol})$ were used. Distillation of the residue under reduced pressure $\left(90^{\circ} \mathrm{C} / 0.3 \mathrm{mmHg}\right)$ gave a colorless oil $8.6 \mathrm{~g}(55 \%)$ of (11).

GC/MS (m/e, \%) $244\left(\mathrm{M}^{+}, 17\right), 229\left(\mathrm{M}^{+}-1,17\right), 185$ (100). ${ }^{1} \mathrm{H} \mathrm{NMR}\left(\mathrm{CDCl}_{3}\right) \delta 0.44\left(\mathrm{~d}, \mathrm{SiCH}_{3}, J=4 \mathrm{~Hz}, 12 \mathrm{H}\right)$, 4.57 (sept., $\mathrm{Si}-H, J=4 \mathrm{~Hz}, 2 \mathrm{H}$ ), 7.62 (d, aromatic, $J=$ $8 \mathrm{~Hz}, 2 \mathrm{H}), 7.84(\mathrm{~d}$, aromatic, $J=8 \mathrm{~Hz}, 2 \mathrm{H}), 8.04$ (s, aromatic, $2 \mathrm{H}$ ).

\section{Preparation of Crosslinked PCS (Table II)}

PCS III-PCS X was prepared in a similar manner as follows (Scheme 2).

Monomer (5) (3.64 g, $11.3 \mathrm{mmol})$, monomer (2) (1.36 g, $5.7 \mathrm{mmol}$ ), dimethyl maleate ( $33 \mathrm{mg}$ ), and Pt catalyst (23 $\mathrm{mg}, 9.71 \times 10^{-5} \mathrm{mmol} \mathrm{mg}^{-1}$ ) were dissolved in $\mathrm{THF}$ $(2 \mathrm{~mL})$. The solution was poured into a metal can $(67$ $\mathrm{mm}$ in diameter; $5 \mathrm{~mm}$ in depth), the inner surface of which was covered with polyimide film (APICAL $25 \mathrm{AH}$, Kaneka Corporation) so as to remove the cured specimen without difficulty. The can was covered with a lid and placed in an oven at $50^{\circ} \mathrm{C}$ for $17 \mathrm{~h}$, and additionally heated stepwise $\left(80^{\circ} \mathrm{C} / 5 \mathrm{~h} \rightarrow 100^{\circ} \mathrm{C} / 21 \mathrm{~h} \rightarrow 150^{\circ} \mathrm{C} / 24 \mathrm{~h}\right)$. The cured sample (1.2 mm thickness) was transparent without cracks or bubbles. Gel content was $100 \%$ as measured as follows: A piece of cured specimen (ca. 200 $\mathrm{mg}$ ) wrapped in a stainless steel net was immersed in THF (ca. $200 \mathrm{~mL}$ ) for $12 \mathrm{~h}$. Gel content here was defined as residual weight of the sample after dipping and drying $\left(100^{\circ} \mathrm{C} / 4 \mathrm{~h}\right)$. Other crosslinked PCS samples were prepared in a similar manner.

\section{RESULTS AND DISCUSSION}

\section{Synthesis of Monomer}

Carbosilane monomers (5)-(12) were prepared Grignard reaction using chlorosilanes and dibrominatedaromatic compounds as starting materials (Scheme 1). Yields of the monomers were low, and isolated yield of (9) was only $28 \%$ (see Experimental Section). Monosubstituted compounds were obtained as by-products in all reactions, probably due to the low reactivity of Grignard reagents. The lithium reagents of the dibrominated species may thus lead to high yields of carbosilane monomers.

\section{Preparation of Crosslinked PCSs}

Crosslinked PCSs (Scheme 2) were prepared using hydrosilylation curing reaction between multi-functional vinylsilanes and hydrosilanes (Table II, see EXPERIMENTAL Section). Curing reaction was performed with, by casting, heating stepwise $\left(50 / 80 / 100 / 150^{\circ} \mathrm{C}\right.$ or $\left.250^{\circ} \mathrm{C}\right)$. Hydrosilylation reactions were catalyzed by the $1,3-$ divinyltetramethyldisiloxane-platinum complex (Karstedt's catalyst). ${ }^{10}$ Crosslinked PCSs were transparent

Table III. Physical properties of crosslinked PCSs ${ }^{a}$

\begin{tabular}{lrrr} 
& & & \\
& & & \\
& & & \\
& & & \\
\hline PCS III & Transparent, rigid & $136^{\circ}$ & 100 \\
PCS IV & Transparent, rigid & $32^{\mathrm{b}}$ & 94 \\
PCS V & Transparent, rigid & $65^{\mathrm{b}}$ & 96 \\
PCS VI & Transparent, rigid & $183^{\mathrm{c}}$ & 100 \\
PCS VII & Transparent, rigid & $218^{\mathrm{c}}$ & 100 \\
PCS VIII & Transparent, rigid & $250^{\mathrm{c}}$ & 100 \\
PCS IX & Transparent, rigid & $200^{\mathrm{C}}$ & 100 \\
PCS X & Transparent, rigid & $257^{\mathrm{c}}$ & 100 \\
\hline
\end{tabular}

${ }^{\mathrm{a}}$ Structures are shown in Scheme 1. ${ }^{\mathrm{b}}$ By DSC. ${ }^{\mathrm{c}}$ By DMA.

Table IV. Flexural properties of crosslinked PCS III-V at $23^{\circ} \mathrm{C}$

PCS III


Table V. Flexural properties of crosslinked PCS VI and VII at $23^{\circ} \mathrm{C}$

PCS VII

(a)

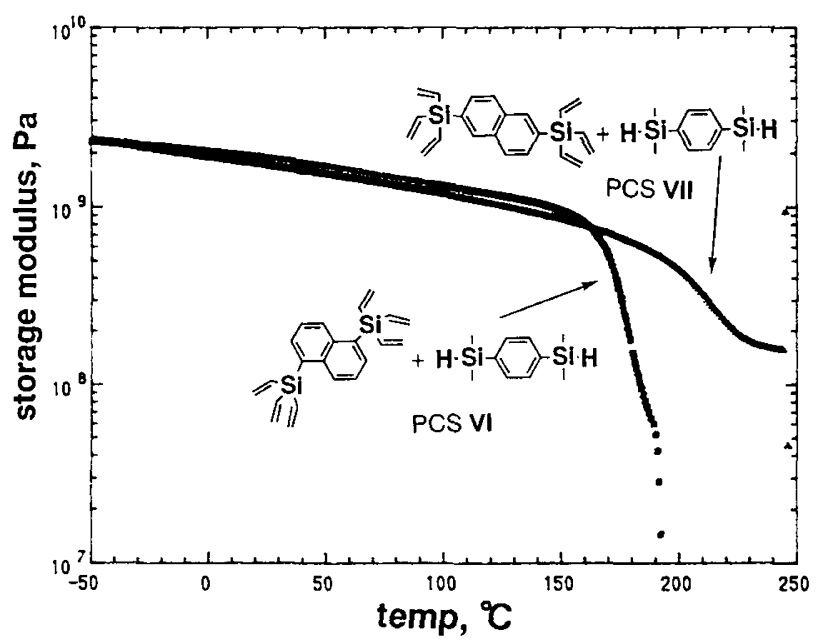

(b)

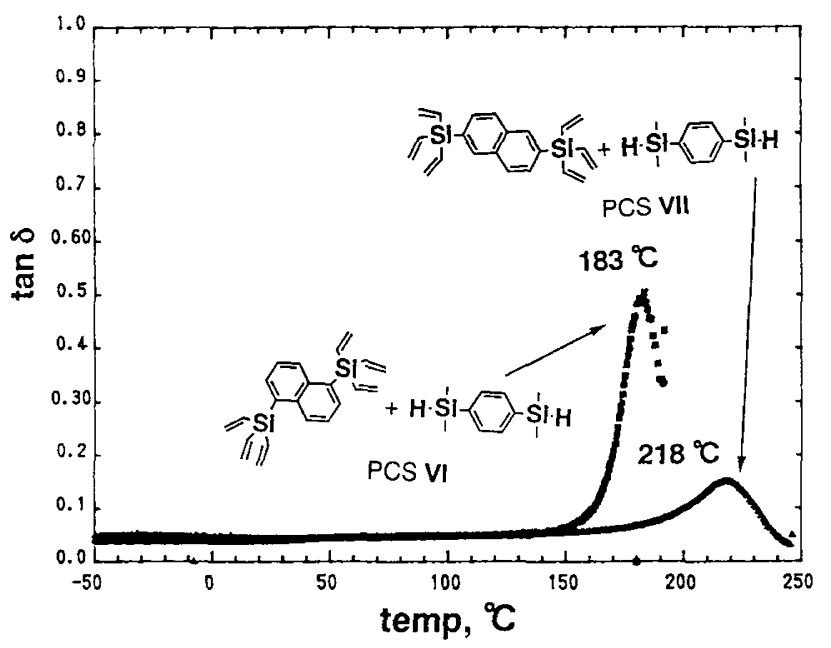

Figure 1. Dependence of (a) storage modulus and (b) tan $\delta$ on temperature for PCS VI and PCS VII measured at 10 Hz.

and rigid materials without cracks. Gel content of obtained PCSs was almost $100 \%$.

\section{Properties and Structures of Crosslinked PCSs}

The authors reported $T_{\mathrm{g}} \mathrm{s}$ and flexural properties of PCS I and II (Table I). ${ }^{7}$ High network chain density and rigid-rod unit $\left[\mathrm{Si}(\mathrm{Me})_{2}-p-\mathrm{C}_{6} \mathrm{H}_{4}-\mathrm{Si}(\mathrm{Me})_{2}\right]$ were found necessary to give high mechanical strength to crosslinked PCSs. Spacer structures were initially optimized to increase $T_{\mathrm{g}} \mathrm{s}$ and flexural properties, and then network chain density. $T_{\mathrm{g}} \mathrm{s}$ were evaluated by DSC or DMA and flexural properties by a three-point bending test (see ExPERIMENTAL Section).

Table III shows $T_{\mathrm{g}} \mathrm{s}$, and Table IV, the influence of structures of spacers on flexural properties. Using monomer (5), for PCS III, $T_{\mathrm{g}}$ increased largely and maximum strength increased slightly compared with the conventional system (PCS I). Using monomer (6), in the case of PCS IV, $T_{\mathrm{g}}$ and maximum strength decreased largely, this possibly related to the high flexibility of ether linkage unit of the monomer (6). Maximum strength of PCS V improved compared with PCS I, $T_{\mathrm{g}}$ decreased slightly.
To improve flexural properties, the introduction of biphenyl and naphthalene linkage was effective.

Table V shows the flexural properties of PCS VI and VII. The influence of the following on properties was evaluated: 1) introduction of trivinylsilyl groups to the napthalene monomers, and 2) positions of trivinylsilyl groups, 1,5-substitution or 2,6-substitution. $T_{\mathrm{g}} \mathrm{s}$ of PCSs were not observed by DSC. Therefore, DMA was used. Figure 1 provides plots of (a) storage modulus and (b) $\tan \delta$ against temperatures for PCS VI and PCS VII. The storage modulus indicates static mechanical strength and a peak of $\tan \delta$ corresponds to a $T_{\mathrm{g}}$ by DSC. The storage modulus of PCS VII obtained using 2,6substituted monomer (9), descended slower compared with PCS VI. The peak of $\tan \delta$ of PCS VII shifted to higher temperature, because the 2,6-substituted monomer (9) had higher linearity compared with the 1,5substituted monomer (8). The same was reported for carbon-based polymer, polyamide. ${ }^{11}$ Maximum strength of PCS VI and VII was $68 \mathrm{MPa}, 62 \mathrm{MPa}$, respectively (Table V).

The structures of spacer units were optimized to in- 
(a)

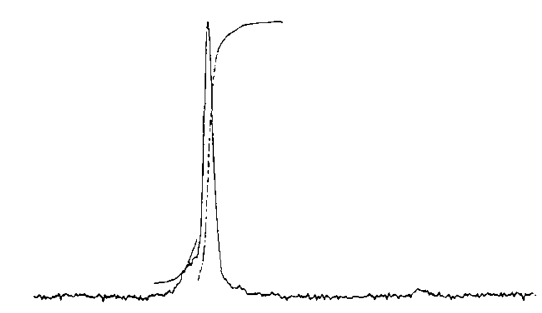

(b)

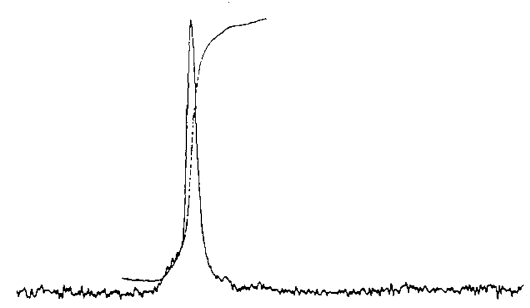

(c)

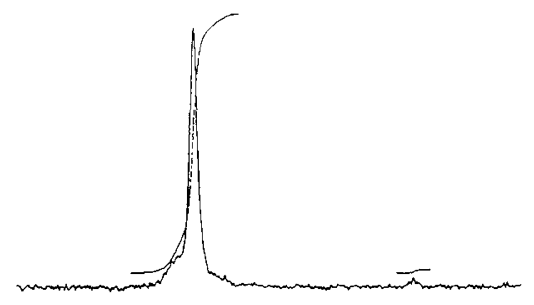

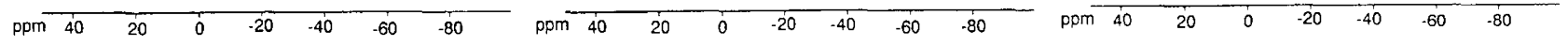

Figure 2. ${ }^{29}$ Si DD/MAS spectra of (a) PCS VIII, (b) PCS IX, and (c) PCS X.

(a)

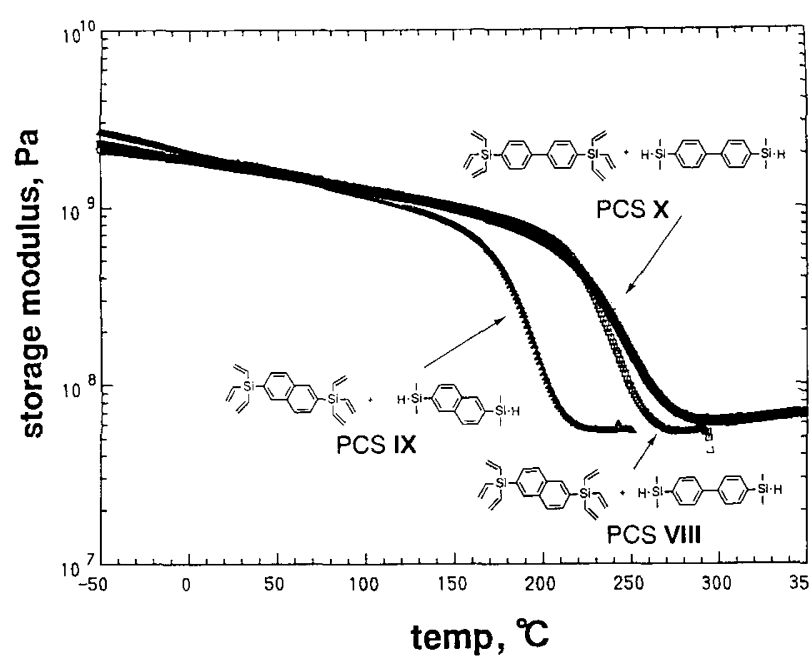

(b)

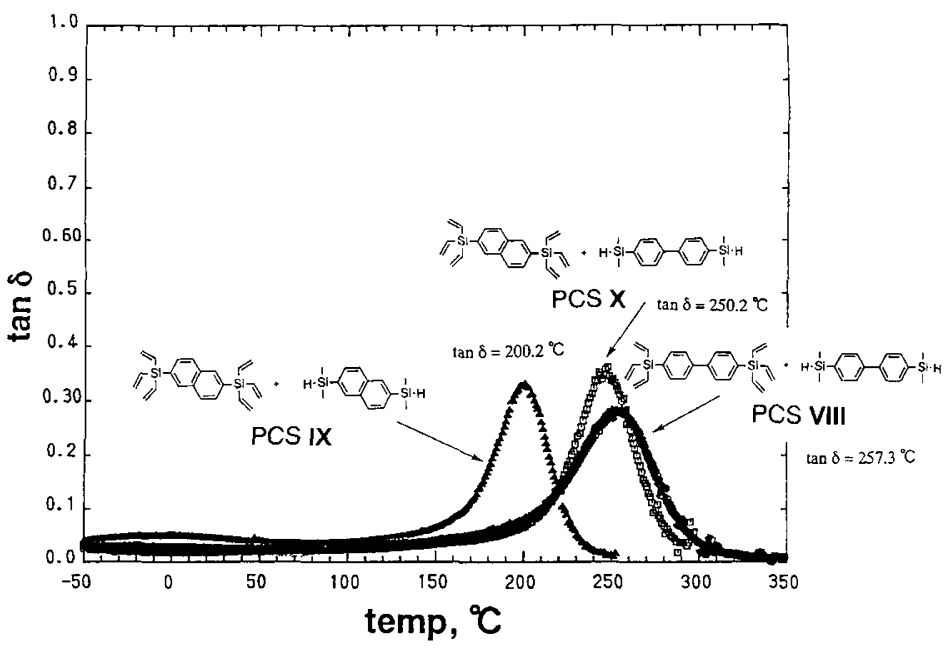

Figure 3. Dependence of (a) storage modulus and (b) tan $\delta$ on temperature for PCS VIII-PCS X measured at $10 \mathrm{~Hz}$.

Table VI. Flexural properties of crosslinked PCS VIII $-\mathbf{X}$ at 23,200 , and $250^{\circ} \mathrm{C}$, respectively.

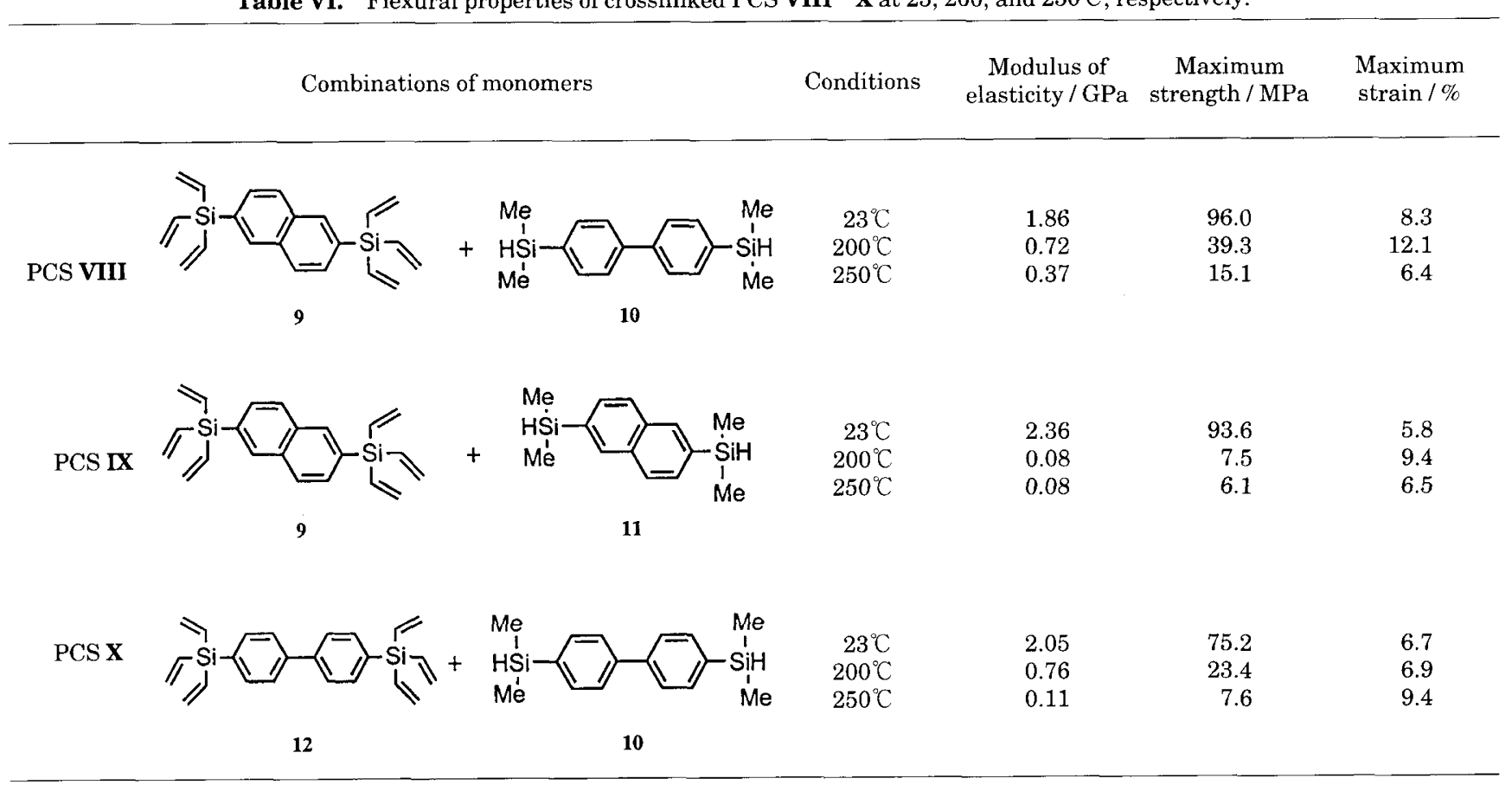




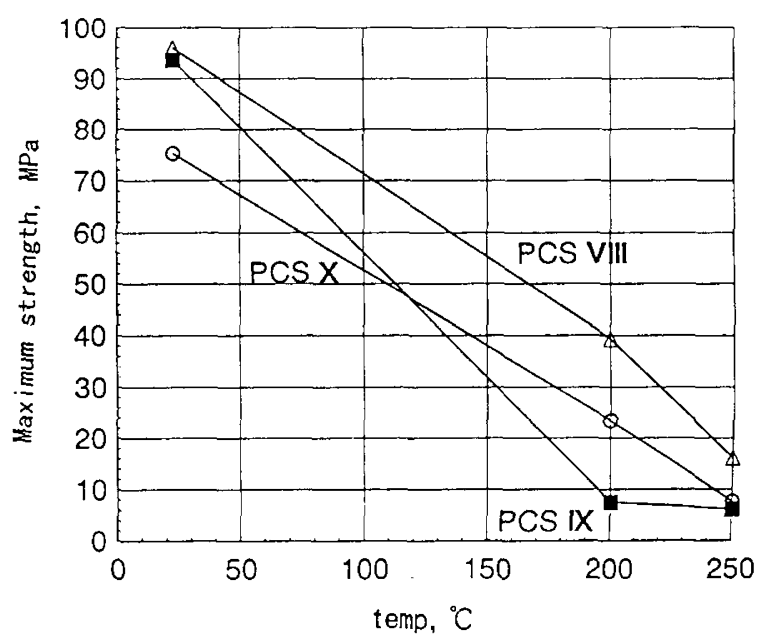

Figure 4. Dependence of maximum strength on temperature for PCS VIII, PCS IX, and PCS $\mathbf{X}$.

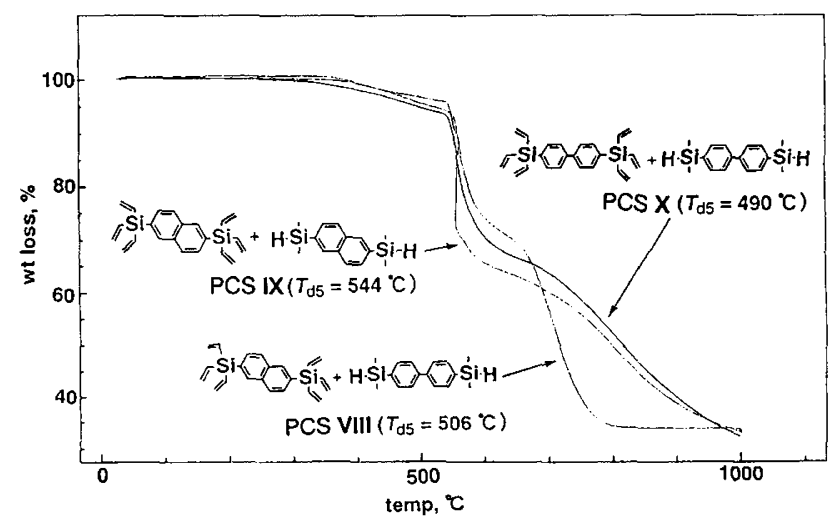

Figure 5. TGA thermograms of PCS VIII, PCS IX, and PCS X in nitrogen.

crease flexural properties. PCS VIII $-\mathbf{X}$ were synthesized (Scheme 2). Figure 2 shows the ${ }^{29} \mathrm{Si}$ NMR spectra of the PCSs. All spectra were almost same. This suggests that the hydrosilylation reactions proceed to same extent. Because signals were unresolved, the conversion of Si-vinyl groups was not able to be estimated. ${ }^{7}$ Figure 3 provides plots of (a) storage modulus and (b) $\tan \delta$ against temperatures. The peaks of $\tan \delta$ of PCS VIII and $\mathbf{X}$ improved drastically. Table VI shows the flexural properties of PCS VIII-X at 23,200 , and $250^{\circ} \mathrm{C}$, respectively. Maximum strength of the PCSs was very high at $23^{\circ} \mathrm{C}$ possibly due to the high crosslinking density and rigid-rod spacer, biphenyl, naphthalene linkage. Maximum strength of the PCS VIII and IX was almost same, and one PCS $\mathbf{X}$ was lower. This would be because the biphenyl linkage is more flexible than the naphthalene linkage. Because of high $T_{\mathrm{g}} \mathrm{s}$, the PCSs may have high thermally mechanical properties. Figure 4 shows the dependence of maximum strength on temperature. PCS VII had the highest thermally mechanical stability. PCS IX, whose $T_{\mathrm{g}}$ was observed at $200^{\circ} \mathrm{C}$, did not retain the flexural strength at higher temperature. Thermally mechanical stability thus increases with $T_{\mathrm{g}}$.

Finally, chemically thermal stability of crosslinked PCSs is discussed. Thermogravimetric behavior of crosslinked PCSs was evaluated (Figure 5). Analysis was performed under a nitrogen stream. Temperatures at $5 \%$ weight loss, $T_{\mathrm{d} 5}$ were observed around $500^{\circ} \mathrm{C}$. Crosslinked PCSs thus have high chemically thermal stability.

\section{CONCLUSIONS}

Crosslinked polycarbosilanes (PCS III-X) were prepared using a hydrosilylation curing reaction between multi-functional vinylsilanes and hydrosilanes. Crosslinked PCSs VIII- $\mathbf{X}$ with high network chain density and rigid-rod spacers, had $T_{\mathrm{gs}}$ at around $250^{\circ} \mathrm{C}$ and high flexural strength in the range of $75-96 \mathrm{MPa}$. Crosslinked PCSs had high chemically thermal stability.

Acknowlegment. This work was performed by Kaneka Corporation, under the management of the Japan Chemical Innovation Institute (JCII), as part of the Industrial Science and Technology Frontier Program supported by the New Energy and Industrial Technology Development Organization (NEDO).

\section{REFERENCES}

1. C. X. Liao, M. W. Chen, L. Sun, and W. P. Weber, Journal of Inorganic and Organometallic Polymers, 3, 231 (1993).

2. S. W. Krska and D. Seyferth, J. Am. Chem. Soc., 120, 3604 (1998).

3. D. S. Kim and S. C. Shim, J. Polym. Sci., Polym. Chem,, 37, 2263 (1999).

4. M. Tsumura and T. Iwahara, Polym. J., 27, 1048 (1995).

5. M. Tsumura and T. Iwahara, J. Polym. Sci., Polym. Chem., 34, 3155 (1996).

6. G. Friedmann and P. S. et J. Brossas, Eur. Polym. J. 29, 1197 (1993).

7. M. Tsumura and T. Iwahara, Polym. J., 31, 452 (1999).

8. A. Pines, M. G. Gibby, and J. S. Waugh, J. Chem. Phys ., 59, 569 (1973).

9. J. Schaefer, E. Stejskal, and R. Buchdahl, Macromolecules, 8 291 (1975).

10. B. D. Karsted, U. S. Patent 3,775,452, 1973.

11. Guey-Sheng. Liou, M. Maruyama, M. Kakimoto, and Y. Imai, J. Polym. Sci., Polym. Chem., 36, 2029 (1998). 